\title{
Biomass Carbon and Nitrogen Content of Wild Fruit Species in Southwest Serbia
}

\author{
Sabahudin Hadrović, Filip Jovanović, Sonja Braunović, \\ Saša Eremija, Zoran Miletić, and Snežana Stajić \\ Institute of Forestry, 3 Kneza Višeslava, Belgrade 11000, Serbia
}

Igor Golić

Forest Enterprise "Milići", 1 Takovska, Milići 75446, Bosnia and Herzegovina

Additional index words. bark, biomass, branches, Central Balkans, european crab apple, wood

\begin{abstract}
To select woody fruit species for biomass cropping, a study of the carbon and nitrogen content of the bark and wood of five wild fruit species in Southwest Serbia was conducted. Compared with common hazel, wild cherry, walnut, and european pear, the european crab apple has a high potential for carbon and nitrogen storage, representing a promising fruit species for biomass production.
\end{abstract}

Serbia is one of the centers of genetic diversity of indigenous fruit species in natural habitats, with more than 100 species. Many wild relatives of cultivated woody fruit species can be used as rootstocks for large-scale production directed toward various applications (Mratinić and Fotirić Aksić, 2019), including the production of biomass. As a renewable source of energy, biomass has to find its proper place, whereas sustainable land management must provide a permanent and stable source of renewable energy (Hadrović et al., 2019).

The element of biomass that largely determines the energy released during oxidation is carbon (C) (Hartmann, 2014). The C content of biomass is usually $45 \%$ to $50 \%$ (by ovendried mass) (Schlesinger, 1991), but this content may vary depending on the species and other factors. Given that selection of species for planting should focus not only on the species that favor the given site conditions, but also on the ones that have greater $\mathrm{C}$ storage capacity, the results of an investigation of the most suitable species for biomass production could make a significant contribution to science and practice (Hadrović et al., 2019). In addition, low nitrogen $(\mathrm{N})$ availability is a major limiting factor for plant growth and development. Uptake, assimilation, storage, and

Received for publication 19 Feb. 2021. Accepted for publication 23 Mar. 2021.

Published online 5 May 2021.

The work was supported by the Ministry of Education, Science and Technological Development (contract no. 451-03-9/2021-14/200027).

F.J. is the corresponding author. E-mail: filip.a.jovanovic@gmail.com.

This is an open access article distributed under the CC BY-NC-ND license (https://creativecommons. org/licenses/by-nc-nd/4.0/). remobilization of $\mathrm{N}$ are key processes in the economy of this essential nutrient, and its efficient metabolic use largely determines vascular development, plant productivity, and biomass production (Cánovas et al., 2018). The content of organically bound $\mathrm{N}$ in biomass is also important because it is related to nitrogen oxide emissions that result after combustion.

Numerous studies on the amount of $\mathrm{C}$ in forest biomass have been conducted in the past few decades (e.g., Vachnadze et al., 2016), including several local investigations (e.g., Koprivica et al., 2013). However, the biomass $\mathrm{C}$ and $\mathrm{N}$ content in woody fruit species has remained insufficiently investigated, although it was studied by others (Bunbury, 1923; Freeman and Peterson, 1941). Hence, our study aims to develop a strategy for the selection of woody fruit species based on their capacity for $\mathrm{C}$ and $\mathrm{N}$ storage.

\section{Materials and Methods}

Biomass samples (branches 10-20 cm long, $>7 \mathrm{~cm}$ thick) of five wild woody fruit species were collected in 2015 at five geographic points in Southwest Serbia: 1) Pyrus communis (lat. $43.03016^{\circ} \mathrm{N}$, long. $20.62177^{\circ} \mathrm{E}$ ), 2) Malus sylvestris (lat. $43.17639^{\circ} \mathrm{N}$, long. $\left.\left.20.48937^{\circ} \mathrm{E}\right), 3\right)$ Corylus avellana (lat. $43.10083^{\circ} \mathrm{N}$, long. $\left.20.36600^{\circ} \mathrm{E}\right)$, 4) Prunus avium (lat. $43.08228^{\circ} \mathrm{N}$, long. $20.36648^{\circ} \mathrm{E}$ ), and 5) Juglans regia (lat. $43.13555^{\circ} \mathrm{N}$, long. $20.44860^{\circ} \mathrm{E}$ ). Each species was represented by a sample plot, five individuals, and a biomass sample per individual, for a total of 25 samples. The bark and core of the samples were analyzed independently.

All samples were oven-dried to a constant weight at $105^{\circ} \mathrm{C}$ and ground in a suitable mill. Sample weights of $30 \mathrm{mg}$ were separated for $\mathrm{C}$ and $\mathrm{N}$ determination in a CHNS analyzer (Elementar $\mathrm{CHN}$ analyzer vario EL III, Hanau, Germany) according to standard procedures (AOAC International, 2006).

Raw data were used to calculate mean values of all parameters and to determine the average \pm SD for every mean. Comparison and determination of the difference between the means were carried out using analysis of variance (ANOVA) with post hoc Fisher's least significant difference (LSD) test. A principal component analysis (PCA) was conducted to show the overall variation and relationships among the samples. Overall differences among the compared groups were defined by squared Euclidean distances used in the cluster analysis. All statistical analyses were performed using Statgraphics software (v. XVI.I.; Statpoint Technologies, Inc., Warrenton, VA).

\section{Results and Discussion}

All species studied, except for the european pear (Pyrus communis L.), had a greater $\mathrm{N}$ content and lesser $\mathrm{C} / \mathrm{N}$ ratio in their bark than in wood; in all species, the $\mathrm{C}$ content was greater in wood than in bark (Table 1). In contrast, in the research of four conifer species in Southwest Serbia (douglas fir, norway spruce, scots pine, austrian pine) (Hadrović et al., 2019), the $\mathrm{N}$ content was mostly low and the $\mathrm{C}$ content was mostly high in bark compared with wood.

ANOVA and the LSD test revealed significant differences $(P<0.05)$ between the means of both studied elements and their ratios in bark, forming three homogeneous groups, whereas in wood, only the $\mathrm{C} / \mathrm{N}$ ratios contributed to the differentiation of species (F $=3.12, P=0.0381)$. Comparing the means, the lowest $\mathrm{C}$ and $\mathrm{N}$ content in bark was found in the european pear (C, 35.39\%; $\mathrm{N}, 1.05 \%$ ), and the highest in the european crab apple [Malus sylvestris (L.) Mill.] (C, $42.56 \%$; N, 2.19\%). In wood, the lowest C/N ratio was determined for the european pear and wild cherry (Prunus avium L.) $(29.00 \%)$, and the highest for common hazel (Corylus avellana L.) (33.60\%) (Table 1). However, as in Hadrović et al. (2019), the values were generally lower than those stated in the literature (Schlesinger, 1991). In comparison with literature data (Freeman and Peterson, 1941), the obtained mean value of $\mathrm{C}$ content in the wood of wild cherry was less than the value stated for fire cherry (Prunus pensylvanica L.f.) $(47.70 \%)$. The same applies to the mean value of $\mathrm{C}$ content in the bark and wood of the european pear compared with the data given by Bunbury (1923) (bark, 48.90\%; wood, $49.90 \%)$. Still, the N content in the bark of the analyzed species was generally greater than the content determined in the bark of four conifer species in Southwest Serbia (Hadrović et al., 2019). Also, in wood, the $\mathrm{C}$ content was greater and the $\mathrm{N}$ content was mostly less in the analyzed species than in the conifers, which makes these species better candidates for biomass production. The critical amount of $\mathrm{N}$ in biomass is $1 \%$ to $2 \%$, and it can be affected by removing plant parts 
Table 1. Descriptive, univariate, and multivariate statistics on carbon $(\mathrm{C})$ and nitrogen $(\mathrm{N})$ contents in the bark and wood of five wild fruit species in Southwest Serbia.

\begin{tabular}{|c|c|c|c|c|c|c|c|c|c|}
\hline & Pyrus communis & Malus sylvestris & Juglans regia & Corylus avellana & Prunus avium & \multicolumn{2}{|c|}{ PCA } & \multicolumn{2}{|c|}{ ANOVA } \\
\hline Cluster & 1 & 2 & 3 & 3 & 3 & & & & \\
\hline N (\%) & $1.05 \pm 0.12 \mathrm{c}^{\mathrm{z}}$ & $2.19 \pm 0.14 \mathrm{a}$ & $1.52 \pm 0.17 b$ & $1.60 \pm 0.20 \mathrm{~b}$ & $1.58 \pm 0.17 b$ & $0.76^{y}$ & 0.52 & 31.63 & 0.0000 \\
\hline C (\%) & $35.39 \pm 2.31 \mathrm{c}$ & $42.56 \pm 2.94 \mathrm{a}$ & $38.19 \pm 2.64 b c$ & $38.05 \pm 2.18 b c$ & $40.02 \pm 2.24 \mathrm{ab}$ & 0.80 & 0.37 & 5.74 & 0.0030 \\
\hline N (\%) & $1.48 \pm 0.11 \mathrm{a}$ & $1.42 \pm 0.15 \mathrm{a}$ & $1.31 \pm 0.16 \mathrm{a}$ & $1.27 \pm 0.22 \mathrm{a}$ & $1.44 \pm 0.14 \mathrm{a}$ & -0.52 & 0.67 & 1.55 & 0.2272 \\
\hline $\mathrm{C}(\%)$ & $43.11 \pm 1.15 \mathrm{a}$ & $44.09 \pm 2.29 \mathrm{a}$ & $42.14 \pm 2.85 \mathrm{a}$ & $42.64 \pm 2.72 \mathrm{a}$ & $41.64 \pm 2.74 \mathrm{a}$ & 0.45 & -0.56 & 0.75 & 0.5707 \\
\hline $\mathrm{C} / \mathrm{N}$ & $29.00 \pm 2.47 b$ & $30.90 \pm 2.50 \mathrm{ab}$ & $32.20 \pm 2.45 \mathrm{ab}$ & $33.60 \pm 3.01 \mathrm{a}$ & $29.00 \pm 2.24 b$ & 0.65 & -0.60 & 3.12 & 0.0381 \\
\hline
\end{tabular}

${ }_{\mathrm{z}}$ Mean \pm SD. Any two means within a row not followed by the same letter(s) are significantly different at $P<0.05$.

${ }^{\mathrm{y}}$ Values in bold type denote variables with factor loadings $>0.7$ for principal component analysis (PCA), and $P<0.05$ for analysis of variance (ANOVA).

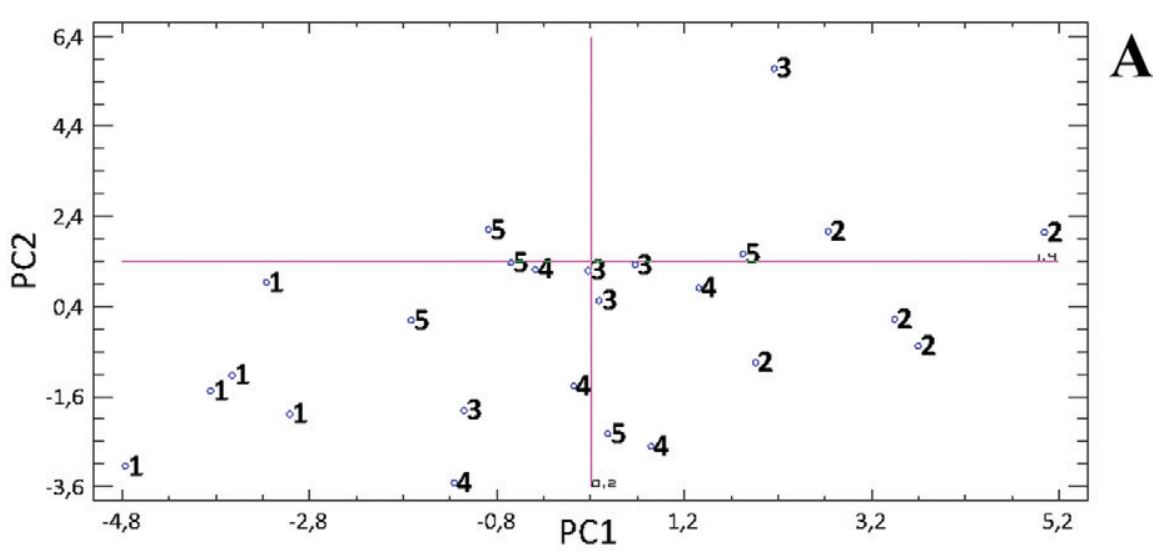

1. Pyrus communis; 2. Malus sylvestris; 3. Corylus avellana; 4. Prunus avium; 5. Juglans regia.

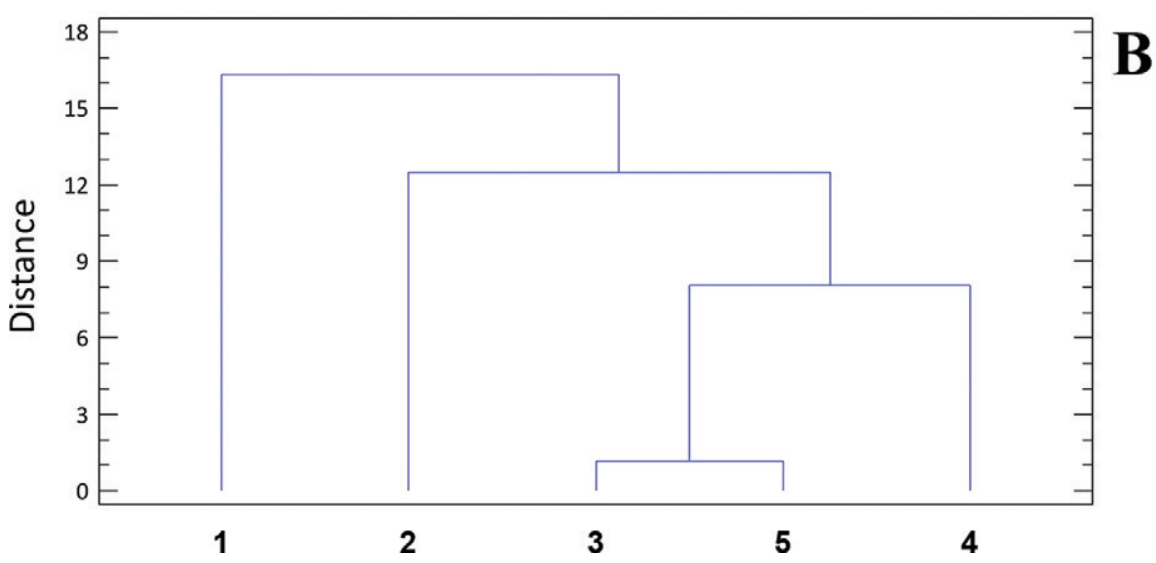

Fig. 1. (A) Principal component (PC) analysis scatterplot and (B) dendrogram of five wild fruit species based on the carbon and nitrogen content in their bark and wood.

that contain high $\mathrm{N}$ concentrations (e.g., bark) (Hartmann, 2014).

In the PCA, the first two principal components, with eigenvalues $>1$, explained $74.64 \%$ of the total variation. The contents of $\mathrm{C}$ and $\mathrm{N}$ and their ratios in bark, with factor loadings $>0.70$, influenced the first axis, which resulted in the separation of species along the same axis. Corresponding to the homogeneous groups established by ANOVA, three groups of species were formed (Fig. 1A). Cluster analysis identified the same orchards of the species' cultivated variants. On the other hand, common hazel has the best $\mathrm{C} / \mathrm{N}$ ratio in wood, but being a small tree or shrub, it is usually less productive. In addition to the environmental site conditions, these data should be considered a significant factor in selecting wild fruit species for biomass cropping.

\section{Literature Cited}

AOAC International. 2006. Method 972.43: Microchemical determination of carbon, hydrogen, and nitrogen: Automated method, p. 5-6. In: Official methods of analysis of AOAC International. 18th ed. AOAC International, Gaithersburg, MD.

Bunbury, H.M. 1923. The destructive distillation of wood. Benn Brothers, London, UK.

Cánovas, F.M., R.A. Cañas, F.N. de la Torre, M.B. Pascual, V. Castro Rodríguez, and C. Avila. 2018. Nitrogen metabolism and biomass production in forest trees. Front. Plant Sci. 9:1449, doi: $10.3389 /$ fpls.2018.01449.

Freeman, R.D. and F.C. Peterson. 1941. Proximate analysis of the heartwood and sapwood of some American hardwoods. Ind. Eng. Chem. Anal. Ed. 13:803-805, doi: 10.1021/i560099a016.

Hadrović, S., S. Eremija, T. Ćirković Mitrović, and L.J. Brašanac Bosanac. 2019. Varijabilnost sadržaja azota i ugljenika u kori i drvetu različitih vrsta četinara u jugozapadnoj Srbiji. Forestry 1/2:133-141. (in Serbian).

Hartmann, H. 2014. Proizvodnja, priprema i svojstva biogenih čvrstih goriva. In: L. Eltrop (ed.) Priručnik o čvrstim biogorivima. Agency for Renewable Resources, Gülzow, Germany. (in Serbian).

Koprivica, M., B. Matović, M. Vučković, and B. Stajić. 2013. Estimation of biomass and carbon stock in uneven-aged beech stands in eastern Serbia. German J. For. Res. 184(1/2):17-25.

Mratinić, E. and M. Fotirić Aksić. 2019. The distribution of wild fruit species in Serbia. Lambert Academic Publishing, Saarbrücken, Germany.

Schlesinger, W.H. 1991. Biogeochemistry: An analysis of global change. Academic Press, New York, NY.

Vachnadze, G.S., Z.T. Tiginashvili, G.V. Tsereteli, B.N. Aptsiauri, and Q.G. Nishnianidze. 2016. Carbon stock sequesteres $[$ sic] from the atmosphere by coniferous forests in Svaneti. Ann. Agrar. Sci. 14(3):269-272, doi: 10.1016/ j.aasci.2016.08.013. 